\title{
PERANGKAT PEMBELAJARAN BIOLOGI BERBASIS MASALAH TERINTEGRASI NILAI-NILAI ISLAMI UNTUK MENINGKATKAN PENGUASAAN KONSEP PESERTA DIDIK
}

\section{MASTERY OF STUDENT CONCEPTS IN BIOLOGY LEARNING USING PROBLEM BASED LEARNING TOOLS INTEGRATED WITH ISLAMIC VALUES}

\author{
Nurul Ihsani ${ }^{1}$, Agil Al Idrus ${ }^{2 *}$, Jamaludin Jamaludin ${ }^{3}$ \\ ${ }^{1}$ Program Studi Magister Pendidikan IPA, Pascasarjana Universitas Mataram, Indonesia \\ ${ }^{23}$ Program Studi Pendidikan Biologi FKIP Universitas Mataram, Indonesia \\ *Email: agilalidrus112015@gmail.com
}

Diterima: 24 Februari 2020. Disetujui: 25 Februari 2020. Dipublikasikan: 2 Maret 2020

\begin{abstract}
Abstrak: Penelitian ini bertujuan untuk mengembangkan perangkat pembelajaran biologi berbasis masalah yang mengintegrasikan nilai-nilai Islam untuk meningkatkan penguasaan konsep siswa. Penelitian pengembangan ini mengacu pada model pengembangan 4D yang terdiri dari tahap Define, Design, Development, Disseminate. Uji validitas perangkat pembelajaran dilakukan oleh tiga ahli pembelajaran biologi sebagai validator. Tes kepraktisan perangkat dilakukan melalui pembelajaran biologi pada peserta didik Kelas X IPA MA. Uji keefektifan perangkat melalui eksperimen dengan desain kelompok kontrol non-pretest-posttest. Hasil uji coba menunjukkan bahwa skor persentase rata-rata validitas perangkat pembelajaran dari ketiga validator adalah $88,62 \%$ dengan kriteria sangat valid. Hasil uji kepraktisan perangkat pembelajaran yang diperoleh dari tanggapan peserta didik dan pendidik adalah rata-rata 90,73\% dengan kriteria sangat praktis. Hasil uji coba keterlaksanaan pembelajaran diperoleh skor rata-rata 89,59\% dengan kriteria sangat praktis. Hasil tes penguasaan konsep biologi di kelas eksperimen diperoleh skor ratarata 70,58\% dengan kriteria tinggi, dan di kelas kontrol nilai rata-rata 34,09\% dengan kriteria sedang. Berdasarkan hasil uji validitas, uji kepraktisan, dan uji efektivitas, perangkat pembelajaran biologi terintegrasi berdasarkan nilainilai Islam yang dihasilkan melalui penelitian dapat dinyatakan valid, praktis dan efektif untuk meningkatkan penguasaan konsep biologi peserta didik di MA.
\end{abstract}

Kata Kunci: Perangkat Pembelajaran Biologi, Model Pembelajaran Berbasis Masalah, Penguasaan Konsep Biologi, nilai-nilai Islami.

\begin{abstract}
This research aims to develop a problem-based biology learning tool integrated Islamic values to improve students' mastery of concepts. This development research refers to the 4D development model which consists of Define, Design, Development, Disseminate stages. The validity test of learning devices was conducted by three biology learning experts as validators. The practicality test of the device was carried out through biology learning on the students of Class X IPA MA Shaykh Zainuddin NW Anjani. Test the effectiveness of the device through experiments with the design of pretest-posttest non equivalent control group. The trial results show that the average percentage score of learning device validity of the three validators is $85.48 \%$ with very valid criteria. The results of the practicality test of learning devices obtained from the responses of students and educators are an average of 90.73 with very practical criteria. The results of testing the implementation of learning obtained an average score of $89.59 \%$ with very practical criteria. The results of concept mastery tests in the experimental class obtained an average score of $70.58 \%$ with high criteria, and in the control class an average value of $34.09 \%$ with moderate criteria. Based on the results of the validity test, practicality test, and effectiveness test, the integrated biological learning tool based on Islamic values generated through research can be declared valid, practical and effective to improve the mastery of the biological concepts of students in MA Shaiykh Zainuddin NW.
\end{abstract}

Keywords: Biology Learning Tools, Problem Based Learning Models, Mastery of Biological Concepts, Islamic Values.

\section{PENDAHULUAN}

Pendidikan memegang peranan yang sangat penting bagi perkembangan suatu bangsa [1]. Berbagai upaya dilakukan oleh setiap negara untuk memperbaiki kualitas pendidikannya. Salah satunya mengenai penguasaan konsep peserta didik terhadap materi yang diajarkan. Penguasaan konsep dalam pendidikan dibutuhkan untuk menghasilkan caracara baru yang berkontribusi terhadap peningkatan mutu pembelajaran [2]. Pentingnya peserta didik memiliki penguasaan konsep karena sebagai kemampuan peserta didik yang bukan hanya sekedar 
memahami, tetapi juga dapat menerapkan konsep yang diberikan dalam memecahkan suatu permasalahan, dan untuk memahami konsep yang baru [3].

Berdasarkan hasil studi lapangan tentang pembelajaran biologi yang telah dilakukan di madrasah aliyah menunjukkan bahwa perangkat pembelajaran yang telah dikembangkan oleh pendidik biologi belum memfasilitasi peserta didik untuk belajar mandiri dan aktif. Strategi pembelajaran yang diimplementasikan dalam pembelajaran biologi belum memfasilitasi peserta didik untuk melatih penguasaan konsep. Metode pembelajaran masih menggunakan metode ceramah dan diskusi sehingga peserta didik cenderung bosan dan pasif dalam kegiatan pembelajaran.

Penguasaan konsep peserta didik cukup rendah. Hal ini dibuktikan dengan rendahnya nilai hasil belajar peserta didik. Hasil belajar mempengaruhi penguasaan konsep peserta didik. Semakin tinggi penguasaan konsep peserta didik maka semakin tinggi hasil belajar [4]. Penguasaan konsep peserta didik dalam pembelajaran biologi sangat diperlukan untuk memahami pengertianpengertian seperti mampu mengungkapkan suatu materi yang disajikan kedalam bentuk yang mudah dipahami, mampu memberikan interpretasi dan mampu mengaplikasikannya.

Upaya dalam meningkatkan kemampuan penguasaan konsep biologi dapat dibangun dengan suatu model pembelajaran serta perangkat pembelajaran yang menghadirkan inovasi-inovasi dengan menggunakan model pembelajaran berbasis masalah untuk memaksimalkan proses berpikir peserta didik. Yustiqvar [5] menjelaskan bahwa pembelajaran yang berpusat pada peserta didik akan membuat penguasaan konsep peserta didik menjadi lebih baik.

Model pembelajaran yang berpusat pada peserta didik adalah model pembelajaran berbasis masalah terintegrasi nilai-nilai islami. Model pembelajaran berbasis masalah berpengaruh positif terhadap hasil belajar peserta didik $[6,7,8]$ Hal ini dikarenakan model pembelajaran berbasis masalah merupakan pembelajaran yang melibatkan peserta didik dalam proses pembelajaran dan menggunakan masalah sebagai fokus pembelajaran [9].

Peneliti mengembangkan perangkat pembelajaran berbasis masalah terintegrasi nilai-nilai islami. Integrasi nilai-nilai islami dalam pembelajaran sains akan memberikan kekuatan pada ranah afektif, psikomotorik dan kognitif [10]. Konsep integrasi Islam dan sains pada pembelajaran dapat menjadi solusi untuk menanamkan nilai-nilai spiritual pada peserta didik dan berkonstribusi menghasilkan manusia yang baik yang mengaplikasikan pengetahuan dan keterampilan sesuai dengan Islam $[11,12]$

Susilawati [12] menyatakan bahwa sains terintegrasi nilai Islam memungkinkan bahan ajar sains diintegrasikan dengan teori agama sehingga akan terbangun teori yang kuat, saling melengkapi, mengkomfirmasi. Pembelajaran yang diintegrasikan dengan nilai agama, mampu memberikan penanaman nilai pada peserta didik tentang ketuhanan yang sesuai dengan konsep sains. Harapannya adalah peserta didik akan memiliki keimanan yang kuat, karena konsep sains yang mereka pelajari terbukti secara ilmiah dan tersirat dalam ajaran agama yang mereka yakini.

\section{METODE PENELITIAN}

Penelitian ini termasuk dalam penelitian dan pengembangan (Research and Development) yaitu penelitian yang digunakan untuk menghasilkan produk tertentu (kreasi), dan menguji keefektifan produk tersebut [13]. Produk yang dimaksud berupa perangkat pembelajaran biologi menggunakan model pembelajaran berbasis masalah untuk meningkatkan penguasaan konsep peserta didik. Pengembangan perangkat pembelajaran biologi dalam penelitian ini mengacu pada model pengembangan 4D yaitu Define, Design, Development, Disseminate [14].

Produk perangkat pembelajaran biologi yang dikembangkan divalidasi oleh tiga tim ahli pembelajaran biologi. Data validasi dari ahli dianalisis secara kualitatif sebagai masukan untuk memperbaiki produk yang dikembangkan. Data angket mengenai tanggapan ahli terkait kelayakan produk pengembangan dianalisis dengan cara mentransformasi nilai rata-rata dari keseluruhan aspek yang diamati kedalam kalimat yang bersifat kualitatif dengan kriteria [15]. Kelayakan perangkat pembelajaran dianalisis berdasarkan respon peserta didik dan pendidik terhadap penggunaan perangkat pembelajaran biologi, serta keterlaksanaan pembelajaran. Analisis peningkatan penguasaan konsep menggunakan rumus $\mathrm{N}$-gain [16]. Tes penguasaan konsep menggunakan tes pilihan ganda. Penelitian ini dilaksanakan selama lima kali pertemuan, setiap pertemuan terdiri dari 135 menit.

\section{HASIL DAN PEMBAHASAN}

Uji kelayakan perangkat pembelajaran yang terdiri dari silabus, RPP, LKPD dan instrumen penguasaan konsep divalidasi oleh 3 orang dosen ahli. Hasil uji kelayakan disajikan pada Tabel 1.

Tabel 1 menunjukkan rata-rata nilai persentase validitas perangkat yang dikembangkan adalah $88,62 \%$ dengan kriteria sangat valid dan layak untuk digunakan. Selanjutnya dilakukan analisis 
kepraktisan perangkat pembelajaran biologi yang diperoleh dari dari respon pendidik dan peserta didik serta keterlaksanaan pembelajaran. Hasil respon peserta didik dan pendidik disajikan pada Tabel 2, sedangkan hasil keterlaksanaan pembelajaran disajikan pada Gambar 1.

Tabel 1. Hasil Validasi Perangkat pembelajaran Biologi

\begin{tabular}{llcl}
\hline No & Perangkat & $\begin{array}{l}\text { Nilai Rata- } \\
\text { Rata }\end{array}$ & Kriteria \\
\hline 1 & Silabus & $92,38 \%$ & Sangat Valid \\
2 & RPP & $90,05 \%$ & Sangat Valid \\
3 & LKPD & $87,33 \%$ & Sangat Valid \\
4 & Instrumen & & \\
& $\begin{array}{l}\text { Penguasaan } \\
\text { Konsep }\end{array}$ & $84,75 \%$ & Sangat Valid \\
\multicolumn{2}{l}{ Rata-rata } & $88,62 \%$ & Sangat Valid \\
\hline
\end{tabular}

Tabel 2. Hasil Respon Pendidik dan peserta Didik terhadap Pengunaan Perangkat pembelajaran Biologi

\begin{tabular}{llcl}
\hline No & Responden & $\begin{array}{l}\text { Nilai Rata- } \\
\text { Rata }\end{array}$ & Kriteria \\
\hline 1 & Pendidik & $95,45 \%$ & Sangat Valid \\
2 & Peserta & $86,02 \%$ & Sangat Valid \\
Didik & 90,73 & Sangat Valid \\
Rata-rata & \\
\hline
\end{tabular}

Tabel 2 menunjukkan bahwa perolehan ratarata persentase hasil respon peserta didik yaitu $86.02 \%$ dengan kategori sangat praktis. Berdasarkan hasil analisis respon peserta didik tersebut dapat di peroleh data bahwa peserta didik memberikan respon yang positif terhadap pembelajaran yang menggunakan perangkat yang telah dikembangangkan.

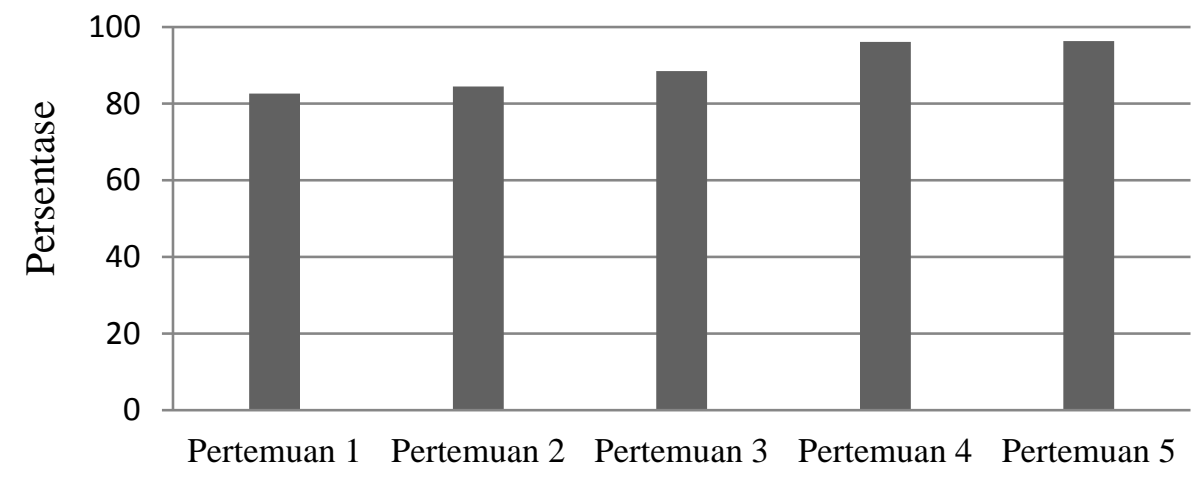

Gambar 1. Hasil keterlaksanaan Pembelajaran

Gambar 1 menunjukkan bahwa presentasi rata-rata hasil keterlaksanaan pembelajaran adalah $89,65 \%$ dengan kategori sangat praktis. Hasil ini menunjukkan bahwa pembelajaran dengan menggunakan perangkat pembelajaran yang telah dikembangkan dapat terlaksana dengan baik

Berdasarkan data hasil analisis kepraktisan diperoleh hasil bahwa rata-rata setiap aspek penilaian kepraktisan memperoleh nilai 95,45\%, 86,02\% dan $89,59 \%$ dengan kriteria sangat praktis. Data kepraktisan menunjukkan bahwa pembelajaran dengan menggunakan perangkat pembelajaran yang dikembangkan memberikan respon positif bagi guru dan peserta didik serta bagi proses pembelajaran di kelas, sehingga praktis dan layak untuk digunakan dalam proses pembelajaran hususnya pada materi pencemaran lingkungan. Suatu model dikatakan praktis apabila fase-fase pembelajaran dapat diimplementasikan oleh guru dengan baik [17]. Hal ini sesuai dengan hasil observasi peneliti pada saat proses pembelajaran berlangsung, seluruh fase kegiatan pembelajaran menggunakan model PBM terintegrasi nilai islami dapat terlaksana dengan baik, meskipun terdapat beberapa kegiatan yang tidak terlaksana dengan baik sesuai dengan RPP yang telah dirancang.

Keterlaksanaaan pembelajaran pertemuan pertama dengan pertemuan berikutnya memiliki persentase keterlaksanaan yang semakin meningkat. Hal ini disebabkan karena pada pertemuan pertama pembelajaran masih bersifat kaku. Guru masih belum terbiasa dengan sintak pembelajaran yang dikembangkan sehingga dalam pelaksanaannya guru masih membaca RPP yang digunakan dalam proses pembelajaran dan membutuhkan alokasi waktu yang lebih banyak dalam pelaksanaannya. Selain itu ada beberapa fase pembelajaran yang tidak terlaksan sehingga menyebabakan persentase keterlaksanaan 
J. Pijar MIPA, Vol. 15 No.2, Maret 2020: 103-109

DOI: 10.29303/jpm.v15i2.1326

pembelajaran pada pertemuan pertama lebih rendah dibandingkan nilai persentase pada pertemuan berikutnya.

Selanjutnya pada pertemuan kedua diperoleh persentase $84,46 \%$ dengan kategori sangat praktis. Pada pertemuan ini catatan dari observer menunjukkan bahwa ada 3 kegiatan pembelajaran yang tidak terlaksana dan waktu yang di habiskan melebihi alokasi waktu yang ditentukan yaitu sebanyak 10 menit, hal ini disebabkan karena Guru lupa dengan tahapan kegiatan pembelajaran yang tertera pada RPP. Hal tersebut mengindikasikan bahwa guru belum terbiasa dengan kegiatan pembelajran yang dikembangkan oleh peneliti. Pada pertemuan pertama dan kedua alokasi waktu tidak sesuai dengan pelaksanaan pembelajaran hal ini disebabkan karena pada kegiatan inti yaitu pada saat praktikum dan presentasi waktu yang digunakan melebihi waktu yang ditentukan sehingga menyebabkan alokasi waktu yang digunakan tidak sesuai dengan alokasi waktu yang di tentukan dalam RPP.

Namun jika dilihat berdasarkan respon peserta didik pada proses pembelajaran, mereka terlihat antusias pada saat praktikum, diskusi dan presentasi. Lebih-lebih saat guru menyajikan ayat al-qur'an yang berkaitan dengan materi pembelajaran peserta didik terlihat sangat antusias dalam menyimak penyampaian guru.

Ketertarikan peserta didik pada kegiatan praktikum dapat terlihat dari keaktifan peserta didik dalam kegiatan praktikum. Pada kegiatan diskusi dan presentasi peserta didik terlihat sangat aktif dalam bertanya dan menyampaikan pendapat serta sanggahan terhadap perbedaan pendapat antara kelompok satu dengan yang lainnya.

Berdasarkan data respon peserta didik yang terdapat pada Tabel 2 menunjukkan perolehan nilai sebesar $89,07 \%$ dengan kategori sangat praktis. Hal ini menunjukkan bahwa peserta didik sangat tertarik pada kegiatan praktikum. Kegiatan praktikum disajikan dalam LKPD yang disusun berdasrkan model PBM kemudian diimplementasikan melalui pembelajaran sehingga menarik minat serta memiliki tingkat penilaian yang positif bagi peserta didik karena kegiatan praktikum tersebut berbeda dengan pembelajaran yang dilakukan sebelumnya (konvensional).

Kegiatan pada LKPD berbasis masalah terintegrasi nilai islami dapat melatih peserta didik berfikir tingkat tinggi, menganalisis suatu persoalan dan menemukan solusinya. Hal tersebut memenuhi prinsip inquiri yang terdapat pada model pembelajaran berbasis masalah yang dikemukakan oleh Hosnan [18] yaitu: (1) adanya keterkaitan antara
ISSN 1907-1744 (Cetak)

ISSN 2460-1500 (Online)

konten dan konteks pengalaman pada kehidupan nyata peserta didik; (2) Kegiatan yang dilakukan melalui penyelidikan; (3) kegiatan diarahkan pada usaha peserta didik untuk membandingkan hipotesis, mengolah data, dan menggeneralisasi; (4) Kegiatan penyelidikan dilakukan dalam kelompopk kecil.

Kegiatan penyelidikan yang dilakukan oleh peserta didik pada saat praktikum secara tidak langsung mempraktikkan inquiri, melatih berfikir kritis, melakukan metode ilmiah serta membangun pengetahuan baru. Hal ini sesuai dengan pernyataan bahwa aktifitas investigasi dapat memfasilitasi peserta didik untuk berlatih dan menyusun informasi serta menerapkan konsep-konsep sehingga pemahaman konsep dan keterampilan berfikir semakin baik [19]. Selanjutnya, pernyataan tersebut didukung oleh pendapat Wahyuningsih [20] yang menyatakan bahwa peserta didik mengintegrasikan konsep baru dengan pengetahuan sebelumnya dalam lingkungan dapat memberikan pemecahan masalah serta meningkatkan kemampuan berpikir.

Aspek integrasi nilai-nilai islam pada pembelajaran dapat diterapkan dengan cara-cara berikut: (1) Selalu menyebut nama Allah; (2) Penggunaan istilah; (3) Ilustrasi visual; (4) Aplikasi atau contoh-contoh; (5) Menyisipkan ayat-ayat atau hadis yang relevan; (6) Penelusuran sejarah; (7) Jaringan topic; dan (8) Simbol ayat-ayat kauniah [21]. Adapun aspek yang digunakan peneliti pada pengembangan perangkat pembelajaran biologi khusunya materi pencemaran lingkungan adalah aspek menyisipkan ayat al-qur'an atau hadits yang relevan dengan materi dan penggunaan istilah islami seperti menggunakan nama-nama islami yang di gunakan pada instrumen penguasaan konsep.

Peserta didik merespon positif terhadap kegiatan pembelajaran yang dilakukan dengan integrasi sains dengan agama disebabkan karena pada mata pelajaran agama yang dipelajari hususnya di madrasah tersebut banyak memiliki keterkaitan dengan sains sehingga mampu melatih kemampuan peserta didik dalam berpikir tingkat tinggi hususnya menganalisis keterkaitan antara sains dengan agama dan memberikan pemahaman konsep yang kuat antara sains dengan agama yang selalu sejalan dan tidak bertentangan. Hasil penelitian terdahulu menunjukkan bahwa perangkat pembelajaran terintegrasi nilai islam dapat meningatan pemahaman konsep peserta didik.

Tabel 3 menunjukkan bahwa perangkat pembelajaran yang diterapkan pada kelas eksperimen memiliki dampak yang cukup positif pada penguasaan konsep peserta didik dibandingkan dengan kelas kontrol yang dibelajarkan menggunakan model konvensional. Nilai rata-rata peserta didik 
J. Pijar MIPA, Vol. 15 No.2, Maret 2020: 103-109

DOI: 10.29303/jpm.v15i2.1326

dapat melewati KKM (Kriteria Ketuntasan Minimum). Hal ini disebabkan karena soal-soal pilihan ganda yang diberikan didominasi seperti contoh-contoh soal-soal yang sering dilatihkan pada proses pembelajaran. Seperti hasil studi pendahuluan sebelumnya, telah diperoleh informasi bahwa peserta didik cenderung lebih tertarik pada pembelajaran biologi yang bersifat aplikatif. Hal tersebutlah tampak pada nilai akhir peserta didik, sehingga nilai yang diperoleh peserta didik tergolong cukup baik. Serta dipengaruhi oleh penerapan model pembelajaran berbasis masalah (PBM) yang terintegarsi nilai-nilai islami.

\section{Tabel 3. Hasil Uji N-Gain Penguasaan Konsep} Biologi

\begin{tabular}{lll}
\hline Kelas & Nilai N-Gain & Kriteria \\
\hline Eksperimen & $70,58 \%$ & Tinggi \\
Kontrol & $34,09 \%$ & Sedang \\
\hline
\end{tabular}

Pembelajaran berdasar masalah dimulai dari masalah yang autentik/ sehari-hari dari kehidupan nyata dan bermakna. Tujuan utama PBM adalah untuk meningkatkan penerapan pengetahuan, pemecahan masalah, dan keterampilan pembelajaran mandiri siswa yang mengharuskan mereka untuk secara aktif mengartikulasikan, memahami, dan memecahkan masalah [22]. PBM terfokus, di mana pelajar mulai belajar dengan membahas simulasi dari suatu masalah otentik. Isi materi pelajaran dan keterampilan yang harus dipelajari diorganisir sekitar masalah, bukan sebagai suatu daftar hirarkis topik, jadi ada hubungan timbal balik antara pengetahuan dan masalah. Belajar dirangsang oleh masalah dan diterapkan kembali ke masalah. PBM juga terpusat pada siswa, memerlukan pelajar untuk diri mengarahkan diri dalam pembelajaran mereka serta menentukan apa yang mereka pecahkan dari masalah yang dihadapi [10]. Pembelajaran berbasis Masalah (PBM) adalah strategi pembelajaran yang menarik, daripada membaca atau mendengar tentang faktafakta dan konsep yang menetapkan bidang studi akademik, siswa memecahkan masalah realistis (meskipun, simulasi) yang mencerminkan keputusan dan dilema orang setiap hari. Sebagian orang berpendapat bahwa PBL adalah strategi pembelajaran yang kuat dan menarik, mengarah pada pembelajaran yang berkelanjutan. PBL mendukung pengembangan strategi belajar mandiri yang memudahkan siswa untuk mempertahankan dan menerapkan pengetahuan serta strategi untuk memberikan solusi pada situasi baru dan asing [23]. Selain itu model PBL dapat memberikan kesempatan pada siswa bereksplorasi mengumpulkan dan menganalisis data untuk memecahkan masalah, sehingga siswa mampu untuk
ISSN 1907-1744 (Cetak)

ISSN 2460-1500 (Online)

berpikir kritis, analitis, sistematis dan logis dalam menemukan alternatif pemecahan masalah [24].

Hasil penelitian ini didukung oleh penelitian yang dilakukan Susilo [22]; Redhana, [24]; Kharida et al, [9]; Reta, [25]; Rahayu et al, [26] yang menyatakan bahwa model pembelajaran berbasis masalah berpengaruh positif terhadap hasil belajar peserta didik. Hal ini dikarenakan model pembelajaran berbasis Model pembelajaran berbasis masalah merupakan suatu model pembelajaran yang menggunakan masalah dunia nyata. Masalah tersebut digunakan sebagai suatu konteks bagi siswa untuk mempelajari cara berpikir kritis dan keterampilan pemecahan masalah, serta untuk memperoleh pengetahuan dan konsep yang esensial dari materi pelajaran [9].

\section{KESIMPULAN}

Melalui penelitian pengembangan ini telah dihasilkan perangkat pembelajaran biologi berbasis masalah terintegrasi nilai-nilai islami. Perangkat pembelajaran dimaksud terdiri atas silabus, RPP, dan LKPD dengan spsifikasi silabus dan RPP mengacu pada permendibud No. 22 tahun 2016 dan disesuaikan dengan sintak model pembelajaran berbasis masalah dan diintegrasikan dengan nilainilai Islami, LKPD disusun berdasarkan sintak model pembelajaran berbasis masalah dan diintegrasikan dengan nilai-nilai Islami. Hasil uji coba menunjukkan bahwa perangkat pembelajaran sangat valid. Hasil uji kepraktisan perangkat pembelajaran dengan kriteria sangat praktis. Hasil uji coba keterlaksanaan pembelajaran dengan kriteria sangat praktis. Hasil tes penguasaan konsep biologi di kelas dengan kriteria tinggi, dan di kelas dengan kriteria sedang. Berdasarkan hasil uji validitas, uji kepraktisan, dan uji efektivitas, perangkat pembelajaran biologi terintegrasi berdasarkan nilai-nilai Islam yang dihasilkan melalui penelitian dapat dinyatakan valid, praktis dan efektif untuk meningkatkan penguasaan konsep biologis siswa di madrasah aliyah.

\section{DAFTAR PUSTAKA}

[1] Sauri, S. (2010). Membangun karakter bangsa melalui pembinaan profesionalisme guru berbasis pendidikan nilai. Jurnal Pendidikan Karakter, 2(2), 1-15.

[2] Artayasa, I P., Susilo, H., Lestari, U., \& Indriwati, S. E. 2018. The Effect of Three Levels of Inquiry on the Improvement of Science Concept Understanding of Elementary School Teacher Candidates. International Journal of Instruction, 11(2), 235-248.

[3] Yustiqvar, M., Gunawan, G., \& Hadisaputra, S. (2019 a). Green Chemistry Based Interactive 
J. Pijar MIPA, Vol. 15 No.2, Maret 2020: 103-109

DOI: 10.29303/jpm.v15i2.1326

Multimedia on Acid-Base Concept. In Journal of Physics: Conference Series (Vol. 1364, No. 1, p. 012006). IOP Publishing.

[4] Yasmin, N., Ramdani, A., \& Azizah, A. (2015). Pengaruh metode inkuiri terbimbing terhadap keterampilan proses sains dan hasil belajar biologi siswa kelas VIII di SMPN 3 Gunungsari tahun ajaran 2013/2014. Jurnal pijar MIPA, 10(2).

[5] Yustiqvar, M., Hadisaputra, S., \& Gunawan, G. (2019 b). Analisis Penguasaan Konsep Peserta didik yang Belajar Kimia Menggunakan Multimedia Interaktif Berbasis Green Chemistry. Jurnal Pijar Mipa, 14(3), 135-140.

[6] Hadisaputra, S., Gunawan, G. \& Yustiqvar, M. (2019). Effects of Green Chemistry Based Interactive Multimedia on the Students' Learning Outcomesand Scientific Literacy. Journal of Advanced Research in Dynamical and Control Systems, 11(7), 664-674

[7] Susilo, A. B. (2012). Pengembangan model pembelajaran IPA berbasis masalah untuk meningkatkan motivasi belajar dan berpikir kritis siswa SMP. Journal of Primary Education, 1(1).

[8] Redhana, I. W. (2012). Model pembelajaran berbasis masalah dan pertanyaan socratik untuk meningkatkan keterampilan berpikir kritis siswa. Jurnal Cakrawala Pendidikan, (3).

[9] Kharida, L. A., Rusilowati, A., \& Pratiknyo, K. (2009). Penerapan model pembelajaran berbasis masalah untuk peningkatan hasil belajar siswa pada pokok bahasan elastisitas bahan. Jurnal Pendidikan Fisika Indonesia, 5(2).

[10] Jonasen, D.H. and Woei Hung. (2008). All Problems are not Equal: Implications for Problem-Based Learning. The Interdisciplinary Journal of Problem-based Learning, 2 (2) : 6 28.

[11] Muspiroh, \& Novianti. (2013). Integrasi Nilai Islam Dalam Pembelajaran IPA (Perspektif Pendidikan Islam). Jurnal Pendidikan Islam. 28(3)

[12] Winarti. 2015. Pengembangan Perangkat Pembelajaran Fisika Bermuatan Integrasi IslamSains untuk Menanamkan Nilai-Nilai Spiritual Siswa Madrasah Aliyah. Jurnal Pendidikan Fisika dan Keilmuan. 1(2): 54-60

[13] Susilowati, S. (2017). Pengembangan Bahan Ajar IPA Terintegrasi Nilai Islam Untuk Meningkatkan Hasil Belajar IPA. Jurnal Inovasi Pendidikan IPA. 3(1), 78-88.

[14] Sugiyono. (2017). Metode Penelitian Kuantitatif, Kualitatif, dan $R \& D$. Bandung: Alfabeta

[15] Thiagarajan., Semmel., \& Sivasailam (1974). Instructional Development for Training Teachers of Exceptional Children. Washington DC:
ISSN 1907-1744 (Cetak)

ISSN 2460-1500 (Online)

National Center for Improvement Educational System.

[16] Ernawati, I., dan Sukardiyono, T. (2017). Uji Kelayakan Media Pembelajaran Interaktif Pada Mata Pelajaran Adiminstrasi Server. Universitas Negeri Yogyakarta. Jurnal Elinvo (Electronics, Informatics, and Vocational Education),2(2)

[17] Hake, R. R. (1999). Analyzing Change/Gain Scores. American Educational. Research Methodology

[18] Siswanto, R. D., Dadan, D, D., Akbar, P., \& Bernard, M. (2018). Penerapan Model Pembelajaran Tipe Auditorial, Intelectually, Repetition (AIR) Untuk Meningkatkan Pemecahan Masalah Siswa SMK Kelas XI. Journal on Eductaion, 1(1), 66-74

[19] Wijayanti, A. (2016). Implementasi model pembelajaran kooperatif tipe tgt sebagai upaya meningkatkan pemahaman konsep fisika dasar mahasiswa pendidikan IPA. Jurnal Pijar Mipa, 11(1).

[20]Rinarta, I. N., Yuanita, L., \& Widodo, W. (2014). Pengembangan Perangkat Pembelajaran Inkuiri Untuk melatihkan Keterampilan proses Sains dan penguasaan Konsep Siswa SMP. Jurnal Pendidikan Fisika, 2(2)

[21]Hanif, Ibrohim, \& Rohman, F. (2016). Pengembangan Perangkat Pembelajaran Biologi Materi Plantae Berbasis Inquiri Terbimbing Terintegrasi Nilai Islam untuk Meningkatkan Pemahaman Konsep Siswa SMA. Jurnal Pendidikan: Teori, Penelitian dan pengembangan. 1(11), 2163-2171

[22] Susilo, A. B. (2012). Pengembangan model pembelajaran IPA berbasis masalah untuk meningkatkan motivasi belajar dan berpikir kritis siswa SMP. Journal of Primary Education. 1(1).

[23] Mergendoller, J.R., Nan L. Maxwell and Yolanda Bellisimo. 2006. The Effectiveness of Problemn Based Instruction: A Comparative Study of Instructional Methods and Student Characteristics. The Interdisciplinary Journal of Problem-based Learning. 1 (2) : 49-69.

[24] Gayatri, I. G. A. S., Jekti, D. S. D., \& Jufri, A. W. (2013). Efektifitas pembelajaran berbasis masalah (PBM) dan strategi kooperatif terhadap kemampuan menyelesaikan masalah dan hasil belajar kognitif biologi ditinjau dari kemampuan akademik awal siswa kelas X SMA Negeri 3 Mataram. Jurnal Pijar Mipa, 8(2).

[25] Reta, I. K. (2012). Pengaruh model pembelajaran Berbasis masalah terhadap keterampilan berpikir Kritis ditinjau dari Gaya kognitif siswa. Jurnal Pendidikan dan Pembelajaran IPA Indonesia. 2(1). 
J. Pijar MIPA, Vol. 15 No.2, Maret 2020: 103-109

ISSN 1907-1744 (Cetak)

DOI: 10.29303/jpm.v15i2.1326

ISSN 2460-1500 (Online)

[26] Rahayu, P., Mulyani, S., \& Miswadi, S. S. (2012). Pengembangan pembelajaran ipa terpadu Dengan menggunakan model pembelajaran problem base melalui lesson study. Jurnal Pendidikan IPA Indonesia. 1(1). 